\title{
The Effect of the Match between the Learning and Teaching Styles of Secondary School Mathematics Teachers on Students' Achievement
}

\author{
Filiz Tuba Dikkartin Övez * Sevinç Mert Uyangör \\ Necatibey Education Faculty, Balikesir University, PO box 10100, Balikesir, Turkey
}

\begin{abstract}
The purpose of this study is to investigate to what extent mathematics teachers teaching at secondary school 6.7. and 8th grade students teach based on students' learning styles and to reveal how effective matching teachers' teaching styles with learners' learning styles in students' achievements is. As this research aims to reveal the case as it is, survey model was used in this study. This study was conducted on 700 secondary school students and 31 teachers who were teaching those students. The study was conducted in 2014-2015 education term at 9 schools which were randomly chosen from Balıkesir Province Center. The data of the study was gathered from 31 secondary school mathematics teachers and 700 secondary school with the help of learning and teaching styles inventory scale. The results of this study reveal that teachers design the learning environments depending on their own learning styles and that there has been a close relationship between teachers' learning styles, students' learning styles and students' achievements in mathematics classes, that students' achievements increase when teaching is done based on their learning styles.
\end{abstract}

Keywords: learning styles, 4MAT styles, teaching styles, achievements, mathematics education

\section{Introduction}

Since 1940s, many views have been proposed suggesting that individual differences and learning styles (LS) need to be considered in education. That every individual has his unique learning ways has brought about the term of LS. Some of these definitions are as follows; Kefee (1979) defines LS as cognitive, affective and psychological behavioural characteristics used as identifiers which do not change to certain extent in styles of perception, interaction, reaction in learning environment. Kolb (1984) considers LS as generalised differences in tendencies of learning which can be measured with an scale that is called as inventory of LS, which base on degree of the four styles of process of learning according to each other. McCarthy $(1987,2000)$ defines LS as individuals' preferences in using skills related to perceiving and processing information. Pedagogues construct different models to design processes of instructional that based on styles of learning in the process of interaction (Veznedaroğlu, 2005). Guild explains the ways for educators to use LS in three different approaches; the first is a view of realization individually and individual centered. According to this approach, it is important for educators to interpret other people's point of views whom they work with. Self-awareness is one dimension of all LS approaches, but some of the LS theories prioritise this issue more than the others, such as Gregorc theory, Jung's psychological types theory and Myers-Brigg's personality types. The second view is to design the curriculum and the implementation to teaching process. This view claims that an extensive model can be developed transfering these differences into teaching programme if it is known that individuals know to learn differently from one another. The followers of this view are Bernice McCarthy, Kathy Butler, Kolb and some other researchers. The third view is diagnostic approach. In this approach, a lot of key issues related to individuals' LS are described. The followers of this view are Rita and Ken Dunn, Marie Carbo and et. al (Brandt, 1990). The models of LS defending the second approach considering those mentioned above have developed various models related to how to transfer LS into other instruction programmes. One of these models is McCharty and 4MAT LS model. 4MAT LS are considered because of the dimension of perceiving and processing information on the base of McCharty LS and having problems of mathematic perception forms of individuals. McCharty LS model is a model which transforms LS concepts into educational strategies. This model is based on Kolb's experimental learning theory in his research findings of brain hemispheres. McCarthy prepared a learning model for primary and secondary education depending on Kolb's LS. He based his model on Kolb's LS which Kolb investigated in four types (McCharthy, 2003). According to Babadoğan (2000), if individuals' LS are determined, it is understood more easily how those individuals learn and what kind of teaching programmes should be designed for them. Thus, teachers can prepare appropriate teaching environments primarily for themselves then for students (Ekici, 2003). In accordance with this aim, the concept of education based on LS begins to be used to emphasize the necessity of consideration to the students' individual differences. Within this scope, teachers' job definition also changes, and it is pointed out that it is necessary for teachers to be guide for students so that they can think more creatively and easily (Peker and Yalın, 2003; Umay, 1996). That way, the coherence the style of teaching of teacher to the style of learning of student is appeared as an important factor. Borg ve Stranahan underline that if preferred styles of teaching accords with LS 
of learners, students achievements increase accordingly. The studies carried out in the field to compare and contrast LS and teaching style (TS) suggest that if the match between teachers' TS and students' LS is high, students' academic achievements also increase accordingly. Besides, these studies also suggest that if teachers' TS match with students' LS, more positive attitudes are obtained (Baleghizadeh, \& Shakouri, 2015; Chafee, 2012; Chen \& Ford, 2001; Felder,1995; Gilakjani, 2012; Hsieh, Jang, Hwang, \& Chen, 2011; Kinshuk, Liu \& Graf, 2009; Spoon,1998; Stitt-Gohdes, 2003; Vaseghi, Ramezani \& Gholami, 2012; Visser\& McChlery, 2006). When we consider the results of the studies carried out in the field, it is suggested to be necessary for teachers to be aware of students' individual differences and their LS in teaching and learning environments. When we consider that Turkey is well below the international averages, the following questions come to people's mind, such as to what extent teachers take students' LS into consideration, and what the effects of such teaching are on students' achievement. Accordingly, the purpose of this study is to investigate the effects of matching TS of teachers that are teaching at secondary school 6. 7. and 8th grade students with learners' LS to students'achievement. The following research questions have been addressed to this study.

i. To what extent do secondary school mathematics teachers implement an instruction in accordance with students' LS?

ii. Is the instruction implementation of degree of teachers based on students' LS significantly different depending on their LS?

iii. Do teachers' degree of instruction implementation based on learners' LS and learners' LS significantly predict to students' academic achievements in Mathematics?

iv. Are students' academic achievements in Mathematics significantly different depending on the common effect of students' LS and teachers' TS?

v. Is there any significant difference between teachers' TS and students' academic achievements in Mathematics whose LS match or do not match with those of teachers?

\section{Method}

2.1 Study Group

As this research aims to reveal the case as it is, survey model was used in this study. This study was conducted on 700 secondary school students and 31 teachers who were teaching those students. The study was conducted in 2014-2015 education term at 9 schools which were randomly chosen from Balıkesir Province Center. 168 of the participants are 6 . grade students, 286 of them were 7 th grade students and 246 of them were 8 th grade students.

\subsection{Evaluation Tools and Data Analysis}

The data of the study was gathered from 31 secondary school mathematics teachers and 700 secondary school students in 2014-2015 education year with the help of implementation of the scale of LS and TS. On the purpose of determining to teachers' and students' LS, Kolb LS Inventory (ÖSE) whose feasibility in Turkey has been proved by Aşkar and Akkoyunlu (1993), which consists of 12 items were conducted on primary school students and their mathematics teachers. According to this style, individuals perceive information by thinking or feeling and process by watching or doing it. Kolb (1984) research LS into four types as changer, assimilator, eluter and establisher. McCarthy designed a learning model for primary and secondary education by changing slightly to Kolb's theory. The model is based on LS researched into four types. As a result of his investigation, McCarthy classifies LS by Type I learners (imaginary students), Type II learners (analytic learners), Type III Learners (Common sense Learners), Type IV learners (Dynamic learners) (McCharthy,2003). On the purpose of identifing to what extent secondary school mathematics teachers implement an instruction based on students' LS, a scale of determination to instruction degree based on LS developed by Peker, Mirasyedioğlu and Yalın (2003) was used in this study. The reliability coefficient of the study was found to be $\alpha=0.97$. The responses given to the items in this scale were graded as "always=5", "often=4", "sometimes=3", "very little=2", "none=1". To reveal the relationship between the LS of the teachers and the degree of instruction implementation based on students' LS, students were requested to evaluate their mathematics teachers by using the scale of determination to instruction degree based on LS. With the average of the scores obtained 53 item scales, mathematics teachers' A1 scores related to the degree of implementing appropriate instruction for Type I learners, A2 scores related to the degree of implementing appropriate instruction for Type II learners, A3 scores related to the degree of implementing appropriate instruction for Type III learners and A4 scores related to the degree of implementing appropriate instruction for Type IV students were obtained. In addition to this, so as to identify to what extent secondary school mathematics teachers implement instruction appropriate to LS in their classes, each teacher was evaluated by the students who they taught, and using the average of the data obtained with the help of this evaluation, which LS considered to be appropriate to instruction by teachers "all the time" were determined and this instruction implemented according to these LS was accepted as dominant TS of the teacher. In the analysis of the data, SPSS package programme was used. To come up with a response to the first research question of this study, frequency (f), percentages (\%) and arithmetical means were calculated and the obtained data was 
descriptively evaluated. For the second reseach question of this study, multivariate analysis of variance (Manova) was used, and for the fourth research question, two-factor Anova was used, for the fifth research question, t-test was used. Stepwise multi analysis was used for the third research question of this study to reveal whether the degree of instruction implementation based on teachers' LS and students' LS significantly predicts students' academic achievements or not. The dependent variable in regression analysis is "mathematics course's academic achievements" (AA), the independent variables are teachers' scores for implementing instruction appropriate to teachers' LS. The (DA1) score related to the degrees of implementing instruction appropriate to Type I learners, the (DA2) score related to the degrees of implementing instruction appropriate to Type II learners, the (DA3) score related to the degrees of implementing instruction appropriate to Type III learners, the (DA4) score related to the degrees of implementing instruction appropriate to Type IV learners are continuous variables and learners' LS which are discrete variables are all grouped into four categories (Type I, Type II, Type III, Type IV). The LS are included in regression analysis coding it as "dummy variable".

\section{Findings and Discussion}

3.1 Study Group Findings Related to What Extent Secondary School Mathematics Teachers Implement The Instruction Appropriate to Students' LS

So as to identify to what extent secondary school mathematics teachers implement the instruction appropriate to students' LS, teachers' LS have been revealed with the use of the findings obtained from "the scale of learning style" carried out on teachers and the scale of determination to instruction degree based on mathematic teachers' LS carried out on students. Besides, the aritmetical mean ranges of data related to what extend teachers implement the instruction appropriate to teachers' LS are as; 1,00-1,80; which means "never apply"; 1,81-2,60; which means "sometimes applies", 2,61-3,40 which means "rarely applies", 3,41-4,20; which means "often applies", 4,21-5,00 which means "always applies". The data obtained in relation to the degrees of mathematics teachers of implementing the instruction appropriate to LS is given in Table 1.

Table 1. The frequency and precentage values related to the degrees of mathematics teachers implement the instruction based on LS.

\begin{tabular}{|c|c|c|c|c|c|c|c|c|c|c|}
\hline \multirow[t]{2}{*}{ Type } & \multicolumn{2}{|c|}{$\begin{array}{l}\text { Never } \\
\text { implement }\end{array}$} & \multicolumn{2}{|c|}{$\begin{array}{l}\text { Very few } \\
\text { implements }\end{array}$} & \multicolumn{2}{|c|}{$\begin{array}{l}\text { Occasionally } \\
\text { implements }\end{array}$} & \multicolumn{2}{|c|}{$\begin{array}{l}\text { Often } \\
\text { implements }\end{array}$} & \multicolumn{2}{|c|}{$\begin{array}{l}\text { Always } \\
\text { implements }\end{array}$} \\
\hline & $\mathrm{f}$ & $\%$ & $\mathrm{f}$ & $\%$ & $\mathrm{f}$ & $\%$ & $\mathrm{f}$ & $\%$ & $\mathrm{f}$ & $\%$ \\
\hline Type I & 190 & 27.1 & 217 & 31 & 227 & 32.4 & 50 & 7.1 & 16 & 2.3 \\
\hline Type II & 79 & 11.3 & 142 & 20.3 & 223 & 31.9 & 179 & 25.6 & 77 & 11.0 \\
\hline Type III & 60 & 8.6 & 121 & 17.3 & 102 & 14.6 & 197 & 28.1 & 220 & 31.4 \\
\hline Type IV & 141 & 20.1 & 213 & 30.4 & 228 & 32.6 & 92 & 13.1 & 26 & 3.7 \\
\hline
\end{tabular}

The role of teacher implementing the instruction appropriate to Type I learners is to associate the meaning with the content. In other words, teachers are those who combine the meaning. Teachers seem to be responsible for building relationship between students' life experiences with the content of the course within the classroom setting, for showing respect to students' personal differences, also for showing respect to personal differences among teachers. According to the percentage frequency results suggesting about to what extent teachers implement the instruction appropriate to Type I, $2.3 \%$ of the teachers always implement such instruction, $27,4 \%$ of them never apply, and $32,4 \%$ of them sometimes apply. Besides, the data obtained with this study suggests that as teacher are solving problems, it is not often for teachers to let students discuss about problems, to request students to visualize the given proglem in their minds to come up with a solution to the given problem. These results show parallelism with those of Peker et. al. (2003). The role of the teachers on implementing the instruction appropriate to Type II learners is to be the teaching leaders in the classes. In other words, teachers are those who build and manage relationship between the structured course subject and conceptualized information unit with meaningful relationships. The frequency results related to what extent teachers implement the instruction appropriate to Type II suggest that $11 \%$ of the teachers always implement such instructions, $11,3 \%$ of them never implement such instructions, and $25,6 \%$ of them often implement and $31,9 \%$ of them sometimes implement such instructions. When the obtained data was examined, the item which has the highest average is that "demands us to know what we learn" $(\mathrm{X}=4.11)$. The item which has the lowest average is "as students are taught, he uses visual and audial aids" $(X=1.28)$. Besides, the items suggesting that "focuses on the logic of a theory rather than its implementation" $(X=2.37)$. On the other hand, Type II learners learn evaluating the accuracy of the learned thing, thought experience and by thinking. Students are those who give significance to systematic thinking, who dig into details and maximize it. The teaching which is not conducted considering this reality may lead positive attitudes, which may then lead decrase in achievement. Considering the data obtained with this study, it can be suggested that the teaching practices appropriate to Type II learners is not conducted sufficiently. The role of the teachers implementing the instructions appropriate to Type II learners are to be supportive and responsible for application. In other words, teachers play a leading role in developing students basic skills, in facilitating, in description of the material to be learned and in the use of and in the combining of 
the material to be learned. The frequency results related to what extent teachers implement the instruction appropriate to Type III suggest that $31,4 \%$ of the teachers always implement such instruction, $8,6 \%$ of them never implement, and $28,1 \%$ of them often implement and $17,3 \%$ of them rarely implement. When we examine the data, it was found that teachers most often conduct their teaching appropriate to Type III learners. The item which has the highest average is "demands students to be active in the third quarter of the class" $(\mathrm{X}=4.27)$. The item which has the lowest average is "assigns the type of activities into which we can add something from us" $(X=2.06)$. however, Type III learners learn evaluating if what they have encountered is feasible or not and by thinking through their life experiences. They are the type of students who combine theory and practice. Learning can be then achieved if such learning experiences are offered to students and if necessary within class activities are conducted. On the other hand, the item which was found to be the least implemented one is "Before giving the solutions of the questions which they assigned us to do, they demand us to come up with solutions". That shows parallelism with that of Peker et. al (2003). The role of the teachers who implement the instruction appropriate to Type IV learners is to help them create more choices. In other words, teachers are those who monitor students' personal discoveries, regulate students' sharings, encourage students to use learning in different dimensions, respect students' original views (B1kmaz, 2002; McCharty,2000). The pertentage frequency results related to what extent teachers implement the instruction appropriate to Type IV learners suggest that $3,7 \%$ of the teachers always conduct such instruction, $20,1 \%$ of them never implement and $13,1 \%$ of them often implement and 30,4\% rarely implement. The item which has the highest average is " helps us to learn trial and error method" $(X=3.71)$. The item with the lowest average is "as teaching a new concept, it helps us to learn by doing and sensing $(X=1.57)$. On the other hand, Type IV learners are good at synthesizing in difficult conditions, compliant with changes, and they can draw logical conclusions when there is no logical reasons, they can solve problems with their instinct. Schools are boring places for those learners (McCharty, 2003). When we examine the data, it is found that teachers teach least to Type I learners and then Type IV learners come. For a good rapport between students and teachers, it is necessary for teacher to bring into classrom new teaching methods speaking to four type of learners. With the help of this, schools will not be boring places for students no more, and they will be able to meet their needs. When the data are analysed, it is seen that teachers show the least tendency to Type I and IV learners. In spite of that, that being less degree of teachers implementing the instruction directed to Type IV learners than those of other types is remarkable.

3.2 The Findings Related to The İnvestigation Of Teachers' LS and the Amount of Teaching Conducted Based on LS

So as to reveal if there is a meaningful relationship between teachers' LS and the amount of teaching that they conduct based on LS, the obtained data with this study was evaluated with the use of one way Manova test. $6,5 \%$ of the teachers whose LS have been determined were found to be Type I learners, $16,1 \%$ of them were found to be Type II learners, $64,5 \%$ of them were found to be Type III learners and $12,9 \%$ of them were found to be Type IV. The vast majority of the teacher participants in this study was found to be Type III learning, which is very eye-cathing result. The Manova test results which was carried out so as to reveal if the scores obtained from the four sub-groups which are placed in teachers' LS inventory scale differ depending on LS are given in Table 2.

Table 2. MANOVA Results applied to the scores of the degree of implementing the instruction according to mathematic teachers' LS

\begin{tabular}{|c|c|c|c|c|c|}
\hline Dependent Variables & LS & $\mathrm{N}$ & $\mathrm{X}$ & $\mathrm{S}$ & $\mathrm{F}$ \\
\hline \multirow{4}{*}{ A1 } & Type I- Learners & 2 & 2.68 & 1.03 & \multirow{4}{*}{32.23} \\
\hline & Type II- Learners & 5 & 2.45 & .30 & \\
\hline & Type III- Learners & 20 & 1.93 & .06 & \\
\hline & Type IV -Learners & 4 & 3.12 & .11 & \\
\hline \multirow{4}{*}{$\mathrm{A} 2$} & Type I- Learners & 2 & 2.34 & .10 & \multirow{4}{*}{114.70} \\
\hline & Type II- Learners & 5 & 4.05 & .13 & \\
\hline & Type III- Learners & 20 & 3.08 & .10 & \\
\hline & Type IV -Learners & 4 & 2.25 & .34 & \\
\hline \multirow{4}{*}{ A3 } & Type I- Learners & 2 & 2.92 & .22 & \multirow{4}{*}{146.83} \\
\hline & Type II- Learners & 5 & 2.27 & .27 & \\
\hline & Type III- Learners & 20 & 3.99 & .21 & \\
\hline & Type IV -Learners & 4 & 1.78 & .29 & \\
\hline \multirow{4}{*}{ A4 } & Type I- Learners & 2 & 2.50 & .66 & \multirow{4}{*}{57.49} \\
\hline & Type II- Learners & 5 & 2.43 & .37 & \\
\hline & Type III- Learners & 20 & 2.39 & .16 & \\
\hline & Type IV -Learners & 4 & 4.08 & .04 & \\
\hline
\end{tabular}


When we examine Table 2, those mathematics teachers who have different LS from one another were found to significantly differ from one another with regards to their average scores obtained from four sub-groups which are also given place in teachers' LS inventory. [Wilks Lambda $(\lambda)=.002, \mathrm{~F}=55.12 ; \mathrm{p}<.05$ ]. That finding shows us that the average score for A1, A2, A3, A4 differs depending on teachers' LS. The MANOVA results related to four sub-groups of the scale suggest that the average scores of implementing the instruction appropriate to Type I learners [F=32.23; $<<.05]$, appropriate to Type II learners [F=114.7; $<.05]$, appropriate to Type III learners $[\mathrm{F}=146.83 ; \mathrm{p}<.05]$ and appropriate to Type IV learners $[\mathrm{F}=57.49 ; \mathrm{p}<.05]$ were found to be significantly different. The one way MANOVA analysis suggests that learning style factor affects to what extent tecahers implement the instruction appropriate to individual's LS, that teachers design teaching environments considering mostly their own LS. This result is also supported by the results of some other studies in the literature (Bilgin \& Bahar, 2008; Hayes \& Allison 1997; Stit-Gohdes 2001). According to these results, we conclude that teachers mostly teach in the way as they learn.

Table 3. The Regression Analysis Results Of The Factors Affecting Students' Math Achievements.

\begin{tabular}{|c|c|c|c|c|c|c|c|c|}
\hline Model & Variable & B & St.Er. & $\beta$ & $\mathrm{t}$ & Binary(r) & Partial(r) & $\mathrm{R}^{2}$ \\
\hline \multirow{2}{*}{ Model 1} & Constant & 56.58 & 1.24 & & 45.59 & & & \multirow[b]{2}{*}{.05} \\
\hline & T3 & 10.08 & 1.61 & .23 & 6.27 & .23 & .23 & \\
\hline \multirow{3}{*}{ Model 2} & Constant & 58.75 & 1.33 & & 44.28 & & & \multirow{3}{*}{.08} \\
\hline & T3 & 8.01 & 1.66 & .18 & 4.83 & .23 & .18 & \\
\hline & $\mathrm{T} 1$ & -13.90 & 3.25 & -.16 & -4.27 & -.22 & -.16 & \\
\hline \multirow{4}{*}{ Model 3} & Constant & 62.49 & 1.49 & & 41.91 & & & \multirow{4}{*}{.11} \\
\hline & T3 & 4.65 & 1.75 & .11 & 2.65 & .23 & .10 & \\
\hline & $\mathrm{T} 1$ & -17.43 & 3.26 & -.20 & -5.33 & -.22 & -.19 & \\
\hline & $\mathrm{T} 4$ & -13.64 & 2.64 & -.20 & -5.16 & -.22 & -.19 & \\
\hline \multirow{5}{*}{ Model 4} & Constant & 72.58 & 2.79 & & 25.98 & & & \multirow{5}{*}{.13} \\
\hline & T3 & 4.67 & 1.73 & .11 & 2.69 & .23 & .10 & \\
\hline & T1 & -17.63 & 3.23 & -.21 & -5.46 & -.22 & -.20 & \\
\hline & T4 & -14.15 & 2.61 & -.21 & -5.41 & -.21 & -.20 & \\
\hline & DA2 & -3.24 & .76 & -.15 & -4.24 & -.14 & -.16 & \\
\hline \multirow{6}{*}{ Model 5} & Constant & 67.39 & 3.15 & & 21.39 & & & \multirow{6}{*}{.15} \\
\hline & T3 & 4.22 & 1.72 & .09 & 2.44 & .23 & .09 & \\
\hline & $\mathrm{T} 1$ & -18.34 & 3.21 & -.22 & -5.72 & -.22 & -.21 & \\
\hline & $\mathrm{T} 4$ & -14.16 & 2.59 & -.21 & -5.46 & -.22 & -.20 & \\
\hline & DA2 & -3.98 & .77 & -.19 & -5.06 & -.14 & -.19 & \\
\hline & DA1 & 2.96 & .86 & .13 & 3.47 & .08 & .13 & \\
\hline \multirow{7}{*}{ Model 6} & Constant & 60.27 & 4.17 & & 14.44 & & & \\
\hline & T3 & 4.364 & 1.72 & .10 & 2.54 & .23 & .09 & \\
\hline & T1 & -18.62 & 3.20 & -.22 & -5.85 & -.22 & -.22 & \\
\hline & $\mathrm{T} 4$ & -14.64 & 2.59 & -.21 & -5.67 & -.22 & -.21 & .16 \\
\hline & DA2 & -3.67 & .79 & -.17 & -4.64 & -.14 & -.17 & \\
\hline & DA1 & 3.05 & .85 & .13 & 3.57 & .08 & .14 & \\
\hline & DA3 & 1.72 & .67 & .09 & 2.58 & .07 & .09 & \\
\hline \multirow{8}{*}{ Model 7} & Constant & 64.67 & 4.68 & & 13.82 & & & \\
\hline & T3 & 4.31 & 1.71 & .09 & 2.51 & .23 & .09 & \multirow{7}{*}{.16} \\
\hline & $\mathrm{T} 1$ & -18.83 & 3.19 & -.22 & -5.90 & -.22 & -.22 & \\
\hline & $\mathrm{T} 4$ & -14.31 & 2.59 & -.21 & -5.53 & -.22 & -.21 & \\
\hline & DA2 & -4.18 & .83 & -.19 & -5.05 & -.14 & -.19 & \\
\hline & DA1 & 4.78 & 1.19 & .20 & 3.99 & .09 & .15 & \\
\hline & DA3 & 1.48 & .68 & .08 & 2.18 & .07 & .08 & \\
\hline & DA4 & -2.65 & 1.29 & -.10 & -2.06 & .03 & -.09 & \\
\hline
\end{tabular}

When we examine Table 3, we see that the LS (T1,T3,T4) and (DA1,DA2,DA3,DA4) have significant relationship with secondary school secondary stage students' achievements in mathematics courses $\left(\mathrm{R}=0.40, \mathrm{R}^{2}=0.16, \mathrm{p}<0.01\right)$. These five dependent variables have been found to justify $16 \%$ of the academic achievement variable. When we examine standardized regression coefficient, the significance order of the variables with regards to their effects on students' academic achievements is as T3, T1, T4, DA2, DA1, DA3, DA4. Considering the obtained data, the obtained regression equation can be suggested as follows; $\mathrm{AA}=64.66+4.31 * \mathrm{~T} 3-18.83 * \mathrm{~T} 1-14.31 * \mathrm{~T} 4-4.18 * \mathrm{IT}+4.78 * \mathrm{DA} 1+1.48 * \mathrm{DA} 3-2.65 * \mathrm{DA} 4$. When we examine the significance of regression analysis coefficient, T2 variable was found to have no effect on achievement ( $p>.01)$. 
When we examine the stages of stepwise regression analysis, $11 \%$ of the $16 \%$ total variance of achievement variable justifies the variables on the first three steps. The variables which have the highest contribution to the equation was suggested to be, in order, DA1,T3. It was also found that T3,DA1,DA3 variables have positive contribution to total variance, T1,T4,DA2,DA4 variables have been found to contribute negatively. When we examine the stages of the analysis, academic achievement variable was found to, at the first stage, justify T3 variable by $05 \%\left(\mathrm{R}=0.23, \mathrm{R}^{2}=.053\right)$, at the second stage, $\mathrm{T} 3, \mathrm{~T} 1$ justify by $08 \%\left(\mathrm{R}=0.28, \mathrm{R}^{2}=.08\right)$, at the third stage, T3,T1,T4 variables were found to justify by $11 \%\left(\mathrm{R}=0.33, \mathrm{R}^{2}=.11\right)$, at the fourth stage, T3,T1,T4,DA2 variables were found to justify by $13 \%\left(\mathrm{R}=0.37, \mathrm{R}^{2}=.13\right)$, at the fifth stage, T3,T1,T4,DA2,DA1 variables were found to justify by $14 \%\left(\mathrm{R}=0.39, \mathrm{R}^{2}=.15\right)$, at the sixth stage, T3,T1,T4,DA2,DA1,DA3 variables were found to justify by $15 \%\left(\mathrm{R}=0.39, \mathrm{R}^{2}=.16\right)$, at the seventh stage, T3,T1,T4,DA2,DA1,DA3,DA4 variables were found to justify by $16 \%\left(\mathrm{R}=0.40, \mathrm{R}^{2}=.16\right)$. According the the regression analysis results, $\mathrm{T} 3$ variable was found to be the variable affecting students' mathematics achievements the most.

3.3 The Findings Related to and The Common Effect of Students' LS and Teachers' LS on The Students Academic Achievements in Mathematics

Two factor ANOVA test was carried out to test whether students' achievement scores differ depending on the common effect of students' LS and the obtained results were given in Table 4.

Table 4. Two Factor ANOVA Results

\begin{tabular}{|l|l|l|l|l|}
\hline Source & Sum of Squares & Sd & Mean of Squares & F \\
\hline TS & 3376.56 & 3 & 1125.52 & 3.43 \\
\hline LS & 3082.30 & 3 & 1027.43 & 3.13 \\
\hline TS * LS & 43892.98 & 9 & 4876.99 & 14.87 \\
\hline Error & 224325.32 & 684 & 327.96 & \\
\hline Total & 3063348.00 & 700 & & \\
\hline
\end{tabular}

When we examine the descriptive statistics and Table 4, the score averages of mathematic academic achievement of the students having Type I learning style as a consequence of the instruction implemented by the teachers having Type I TS can be suggested to be $(X=90.00)$; Type II $(X=65.43)$, Type III $(X=83.69)$ and Type IV $(X=52.00)$. The score averages of mathematic academic achievement of the mathematics teachers having Type II TS, the students having Type I LS is $(\mathrm{X}=54.00)$, Type II is $(\mathrm{X}=76.16)$, Type III is $(\mathrm{X}=47.88)$ and Type IV is $(X=45.33)$. The score averages of mathematic academic achievement of the mathematics teachers having Type III TS, and the students having Type I LS is $(X=43.97)$, Type II is $(X=59.03)$, Type III is $(X=72.20)$; and Type IV is $(\mathrm{X}=49.13)$. The score averages of mathematic academic achievement of the mathematics teachers having Type IV TS, and the students having Type I LS is $(\mathrm{X}=36.25)$, Type II is $(\mathrm{X}=61.58)$ and Type III is $(\mathrm{X}=68.29)$ and Type IV is $(\mathrm{X}=82.50)$. Besides, the ANOVA results suggest that there is a significant difference with regards to the TS $(\mathrm{F}=3.43 ; \mathrm{p}<.05)$ and $\operatorname{LS}(\mathrm{F}=3.13 ; \mathrm{p}<.05)$ of academic achievement means. The obtained data with this study suggests that teachers' TS and learners' LS are significantly effective in mathematics achievements. It was also found that the common effect of LS and TS on mathematics achievements are significant $(\mathrm{F}=14.87 ; \mathrm{p}<.05)$.

3.4 The Relationship Between Teachers' TS and The Students Whose LS Match/Does Not Match With Those Of Teachers'

The students were investigated in two groups as those whose LS match or do not match with dominant styles of teachers and then independent groups t-test was conducted to reveal if the achievements of these groups are significantly different and the obtained data was given in Table 5.

Table 5 The Correlation Between Teachers' Teaching Programmes Matching With Students' LS and Students'

Academic Achievement Means.

\begin{tabular}{|c|c|c|c|c|c|}
\hline & \multicolumn{5}{|c|}{ Academic Achievement } \\
\hline & $\mathrm{N}$ & $\%$ & $\mathrm{~s}$ & $\mathrm{sd}$ & $\mathrm{t}$ \\
\hline Consistency & 405 & 57.9 & 21.04 & 698 & -11.92 \\
\hline İnconsistency & 295 & 42.1 & 17.13 & & \\
\hline
\end{tabular}

The analysis carried out suggests that there is a significant relationship between teachers' TS and students' LS and students' academic achievements if they match with one another $(\mathrm{t}=-11.92, \mathrm{p}<.01)$. It was found that if teachers implement the instruction based on students' LS, students' achievements are higher. The results obtained with this study has parallelism with those of some other studies in the literature (Chen\& Ford,2001; Dinçola, Temel, Oskay, Erdoğan and Y1lmaz,2011; Doming,1979; Felder 1995; Jones,1997; Kinsella, 1995; Muro, Terry, 2007; Nelson 1995; Spolsky 1989; Willing, 1988). 


\section{Conclusions and Implications}

In consideration of the data obtained with this study, it is found that secondary school mathematics teachers implement the instruction appropriate to Type III learner the most and for Type I learners the least. It was also found that there is a relationship between the learning styles that teachers have and the teachers' degree of instruction implementation based on learning styles and teachers mostly design the teaching atmosphere depending on their own learning styles. As a result of the investigation carried out to reveal to what extent the teachers' degree of instruction implementation based on learning styles and its effects on students' achievement in mathematics course, it was found that students' learning styles (T1, T3, T4) and the amount of instruction implemented based on their learning styles (BT, İT, ÜT, DT) were closely related to students' mathematics academic achievements. The results suggest that T3 "Type III learning style" was found to be the most effective variable and "Type IV learning style" was found to be the least effective variable in mathematics academic achievement. It was identified that there was a statistically meaningful relationship between to conform the teaching styles of mathematics teachers in mathematics teaching with students' learning styles and averages of mathematics academic achievements and if students are taught considering their learning styles, their achievements also will increase. The results obtained with this study indicated that teachers are far away from implementing the instruction appropriate to their students learning styles, teachers implement the instruction appropriate to their own learning style by seeing their own learning way as the best teaching way and in parallel with the students who has learning style matching with learning style of teacher are more successful. The importance of educating teachers who considering individual differences of students rather than appropriate instruction curriculum is highly major to be caught up with standards of developed countries in mathematic achievement. The student's style of learning and teacher's style of teaching which consist of the parts of an equation are resulted in failure or achievement in mathematic. Mathematic instruction curriculum that put into practice in 2004 basically admitted the principle of "each child can learn mathematic". Now that each child can learn mathematic, mathematic should be presented considering individual differences and learning styles in the teaching atmosphere of mathematic. So we think that teachers and pre service teachers should be trained about the subject of how they implement mathematic instruction by using models based on learning styles.

\section{References}

Aşkar, P. \& Akkoyunlu, B. (1993). Kolb Öğrenme Stili Envanteri. [Kolb Learning Style Inventory] Ĕ̌gitim ve Bilim, (87), 37-47.

Babadoğan. C. (2000). Öğretim Stili Odaklı Ders Tasarımı Geliştirme. [Teaching Styles Oriented Course Design Development] Milli Ë̈itim Dergisi, 147, 61-63.

Baleghizadeh, S. \& Shakouri, M. (2015). Investigating the relationship between teaching styles and teacher selfefficacy among some Iranian ESP university instructors. Innovations in Education and Teaching International, DOI: 10.1080/14703297.2015.1087329

Bıkmaz, H. F. (2002). Translation: Bernice McCarty, educational leadership. Ankara Üniversitesi Ĕ̈itim Bilimleri Fakültesi Dergisi, (34),1-2,

Bilgin, İ. \& Bahar, M. (2008). Sınıf öğretmenlerinin öğretme ve öğrenme stilleri arasındaki ilişkinin incelenmesi. [Investigation of the Relationship Between Teaching and Learning Styles of Primary School Teachers]. Gazi Üniversitesi, Gazi Ë̆itim Fakültesi Dergisi, 28(1), 19-38.

Borg. M. O. \& Stranahan. H. A. (2002). Personality type and student performance in upper level economics courses: The importance of race and gender. Journal of Economic Education. 33(1). 3-14.

Brandt, R. (1990). On Learning Styles: A Conversation with Pat Guild. Educational Leadership, 48(2), 10-13.

Chen S.\& Ford. N (2001). Matching/mismatching revisited: an empirical study of learning and teaching styles. British Journal of Educational Technology. 32 (1), 5-22(18)

Dinçola, S., Temel, S., Oskay,Ö., Erdoğan, Ü.\& Yılmaz, A. (2011). The effect of matching learning styles with teaching styles on success. Procedia Social and Behavioral Sciences 15 854-858

Doming, G. (1979). Interactive effects of achievement orientation and teaching style on academic achievement. ACT Research Report, 39, 1-9.

Ekici, G. (2003). Öğrenme Stiline Dayalı Öğretim ve Biyoloji Dersi Öğretimine Yönelik Ders Planı Örnekleri. Gazi Kitabevi, Ankara.

Felder. R.M. (1995) Learning and teaching styles in foreign and second language education. Foreign Language Annals 28.1: 21-31.

Gilakjani, P.A. (2012). A Match or Mismatch Between Learning Styles of the Learners and Teaching Styles of the Teachers. Modern Education and Computer Science in MECS Retrieved 4 February 2014 from $<\mathrm{http}$ ://www.mecspress.org $>$.

Hayes. J.\& Allinson. C. W. (1997). Learning Styles and Training and Development in Work Settings: Lessons from Educational Research. Educational Psychology (17). 1-2.185-193.

Hsieh, S. W., Jang, Y. R., Hwang, G. J., \& Chen, N. S. (2011). Effects of teaching and learning styles on 
students' reflection levels for ubiquitous learning. Computers \& Education, 57(1), 1194-1201.

Jones, N.B. (1997) Applying learning styles research to improve writing instruction. Paper presented at RELC Seminar on Learners and Language Learning, Singapore.

Kefee, J. W. (1979). Learning style: An overview. In NASSP's Student learning styles: Diagnosing and prescribing programs (pp. 1-17). Reston, VA: National Association of Secondary School Principals.

Kinshuk, Liu, T. C., \& Graf, S. (2009). Coping with mismatched courses: students' behaviour and performance in courses mismatched to their learning styles. Educational Technology Research and Development, 57(6), 739-752.

Kinsella, K. (1995) Understanding and empowering diverse learners in ESL classrooms. In J.M. Reid, Learning styles in the ESL/EFL classroom. Boston: Heinle \& Heinle. 170-94.

Kolb, D. A. (1984). Experiential learning: Experience as the source of learning and development. New Jersey: Prentice-Hall.

McCarthy, B. (1987). The 4MAT System: Teaching to Learning Styles with Righ/Left Mode Techniques. Barrington: Excel, Inc

McCarthy.B. (2000). About Learning. Published by Abour Learning.Inc.

McCharthy.B. (2003). About Teaching. Companion the 4MAT Implementation Workbook. Published by About Teaching.Inc.

Nelson, G.L. (1995) Cultural differences in learning styles. In J.M. Reid, Learning styles in the ESL/EFL classroom. Boston: Heinle \& Heinle. 3-18.

Peker M., Mirasyedioğlu Ş., Yalın H.İ. (2003). Öğrenme Stillerine Dayalı Matematik Öğretimi,[The Mathematics instruction based on learning styles] Türk Eğitim Bilimleri Dergisi, Cilt 1, Say1 4, $371-384$.

Peker, M. \& Yalın H.İ. (2003). Matematik Öğretmenlerinin Öğrencilerin Öğrenme Stillerine Uygun Öğretim Yapma Düzeyleri ile Ilgili Öğrenci Görüşleri. [Students' opinions about Math teachers' degree of instruction implementation based on learners' learning styles]. V. Ulusal Fen Bilimleri ve Matematik Eğitimi Kongresi

Paola Di Muro \& Marion Terry (2007) A Matter of Style: Applying Kolb's Learning Style Model to College Mathematics Teaching Practices, Journal of College Reading and Learning, 38:1, 53-60, DOI: $10.1080 / 10790195.2007 .10850204$

Stitt-Gohdes. W. L. (2003). Student Teachers and Their Students: Do Their Instructional and Learning Preferences Match?. Business Education Forum 57. no. 4 . 22-27.

Spolsky, B. (1989) Conditions for second language learning. Oxford University Press.

Spoon. J. C. and Schell. J. W. (1998). Aligning Student Learning Styles with Instructor Teaching Styles.. Journal of Industrial Teacher Education 35. no. 2: 41-56.

Umay. A. (1996). Matematik Eğitimi ve Ölçülmesi.[ Mathematics Education and Its Measurement]. Hacettepe Üniversitesi Ĕ̆itim Fakültesi Dergisi. 12. ss.145- 149.

Vaseghi, R., Ramezani, A., E. and Gholami, R. (2012) Language Learning Style Preferences: A Theoretical and Empirical Study. Advances in Asian Social Science (AASS), 2, 2, 441-451

Veznedaroğlu, R.L., Özgür, A.O. (2005). Öğrenme stilleri: tanımlamalar, modeller ve işlevleri.[ Learning Styles: Definitions, models and functions]. Ilkögretim Online, 4(2), 1-16.

Visser. S. \& McChlery.S. (2006). Teaching styles versus learning styles in the accounting sciences in the United Kingdom and South Africa: a comparative analysis. Meditari Accountancy Research Vol. 14 no. 2 : 97 112

Willing, K. (1988) Learning styles in adult migrant education. Adelaide, Australia: NCRC/AMEP. 